\title{
FEATURE The roles and benefits of wetlands in managing reactive nitrogen
}

\author{
Donald L. Hey, Jill A. Kostel, William G. Crumpton, William J. Mitsch, and Brian Scott
}

R eactive nitrogen (i.e., organic nitrogen and biologically and chemically active forms of inorganic nitrogen) has huge beneficial effects, particularly for humans, but it also has equally disastrous effects for humans (Birch et al. 2011) and for the environment, which sustains our presence on this planet (Moomaw 2002; Galloway et al. 2003). Since World War II, the anthropogenic release of reactive nitrogen to the atmosphere, land, and water has greatly increased (Howarth et al. 2005). This has adversely affected atmospheric visibility, climate, and human health, while at the same time led to the acidification of land and water and eutrophication of fresh and salt water ecosystems (Galloway et al. 2003). As troubling as they appear to be, these effects have not been well documented or quantified. Nitrogen (N) loads to streams and rivers in the Mississippi River Watershed are of particular importance because of hypoxia in the Gulf of Mexico (Rabalais 2002; Rabalais et al. 2002a, 2002b) and the associated ecological and economic consequences (Diaz and Solow 1999). Of the $\mathrm{N}$ transported by the Mississippi River and its tributaries, about $60 \%$ of the total is in the form of nitrate $\left(\mathrm{NO}_{3}\right)$ (Goolsby and Battaglin 2000). Both point and non-point sources significantly contribute to the $\mathrm{N}$ load-approximately two-thirds from agriculture and one-third from other sources, including urban runoff, atmospheric deposition, and point sources (Goolsby and Battaglin 2000).

Donald L. Hey is the director of Wetlands Research Inc., Wadsworth, Illinois. Jill A. Kostel is the senior environmental engineer at The Wetlands Initiative, Chicago, Illinois. William G. Crumpton is an associate professor in the Department of Ecology, Evolution, and Organismal Biology, lowa State University, Ames, lowa. William J. Mitsch was director of the Wilma H. Schiermeier Olentangy River Wetland Research Park, Ohio State University, Columbus, Ohio, at the time the article was written; he is now the director of Everglades Wetland Research Park, Florida Gulf Coast University, Naples, Florida. Brian Scott is an assistant professor in the Departments of Economics and Environmental Studies, Washington College, Chestertown, Maryland.
Regardless of the medium into which reactive $\mathrm{N}$ is released, much of the emitted load ends up in the aquatic environment. Reactive $\mathrm{N}$ in the atmosphere returns to the terrestrial and aquatic environments via wet and dry deposition. Most of the $\mathrm{N}$ reaching the terrestrial environment, whether directly or indirectly, is dissolved in surface runoff and in percolating soil water and, thereby, is conveyed to streams, rivers, lakes and wetlands before being released to estuaries and oceans. Once reactive $\mathrm{N}$ is released to the biosphere (Galloway et al. 2003), the aquatic medium (streams and wetlands especially) offers the greatest opportunity for effective, efficient, and sustainable control (in this paper, management or control implies reducing or minimizing the deleterious effects of reactive $\mathrm{N}$ ). During the interval that reactive $N$ resides within aquatic ecosystems upstream of the estuaries and oceans, it is relatively accessible to human control. The spatial distribution and extent of the aquatic medium is more limited and well defined than that of atmospheric and terrestrial media. The aquatic medium is accessible by land and water; its current direct economic value is relatively low; and, if properly managed, it uses solar energy to do most of the necessary work within flood, thermal, and temporal constraints. In the following discussion, $\mathrm{NO}_{3}$ serves as the surrogate for all the species comprising reactive $\mathrm{N}$. The physical, chemical, and biological processes, facilitated by the aquatic environment, particularly wetlands, are generally applicable to all of the components (figure 1).

The potential for using the aquatic medium as a principal means of control does not diminish the importance of source control (Mitsch et al. 1999, 2001). If less reactive $\mathrm{N}$ is emitted, then less external control is needed. In some cases, however, source control can be ineffective, inefficient, and not readily sustainable. For example, municipal and industrial wastewater treatment plants in the Mississippi River Basin emit approximately $1 \%$ of the nitrate-nitrogen $\left(\mathrm{NO}_{3}-\mathrm{N}\right)$ reach- ing the Gulf of Mexico (Goolsby et al. 1999). Given the proper mandate, equipment, and operation, a well-run treatment plant today can effectively nitrify ammonia $\left(\mathrm{NH}_{3}\right)$ to $\mathrm{NO}_{3}$ in order to reduce the immediate oxygen demand and ecotoxicological effects of $\mathrm{NH}_{3}$. This reduces the local effects of one species of reactive $\mathrm{N}$, but it does not decrease the total reactive $\mathrm{N}$ load or the more distant or downstream effects of $\mathrm{NO}_{3}$. Hypoxia in the Gulf of Mexico illustrates this point. Furthermore, the production of the needed increased energy results in the emission of additional reactive $\mathrm{N}$ and other deleterious constituents (e.g., mercury) to the atmosphere. Neither the reactive $\mathrm{N}$ nor the other contaminants remain in the atmosphere. They eventually return to the terrestrial and, ultimately, the aquatic environments through wet and dry deposition.

To address the adverse effects of nutrients on water quality, various programs and regulations have been implemented to control $\mathrm{N}$ effluents from municipal and industrial wastewater treatment plants. To eliminate the problems of toxicity associated with ammonia-nitrogen and nitrogenous oxygen demand (NOD), nitrification is used to convert $\mathrm{NH}_{3}$ to $\mathrm{NO}_{3}$. Today, the US Environmental Protection Agency (USEPA) is requiring many wastewater treatment plants to reduce all forms of reactive $\mathrm{N}$, including $\mathrm{NO}_{3}$ that they discharge to water bodies. To broadly accomplish this reduction, large investments in capital and energy resources will be required. Unless the treatment technologies convert all forms of $\mathrm{N}$ in the waste stream to the nonreactive $\mathrm{N}_{2}$, this will only shift the initial point of reactive $\mathrm{N}$ emission from the aquatic medium to the atmospheric medium. The ultimate receptor remains the same-the aquatic medium. While wastewater treatment technology could be improved and advancements are being made, more effective and efficient technology will not be implemented in the near future. One alternative to improving treatment is reducing the source load of reactive 


\section{Figure 1}

Sources and pathways of reactive nitrogen (adapted from Galloway et al. 2003).

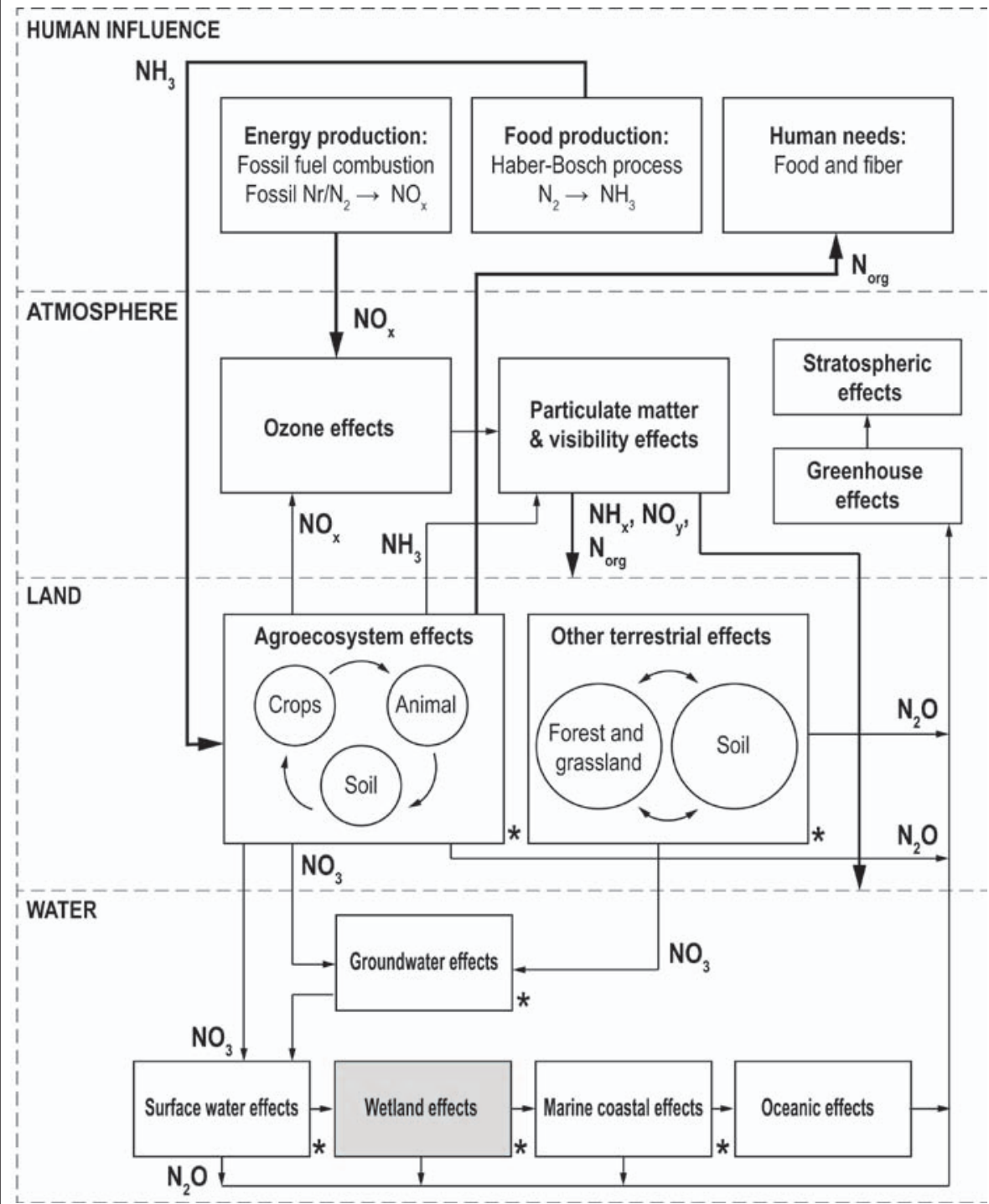

* Indicates denitrification potential within system.

Notes: $\mathrm{NH}_{3}=$ ammonia. $\mathrm{NH}_{4}{ }^{+}=$ammonium. $\mathrm{NH}_{\mathrm{x}}=\mathrm{NH}_{3}$ and $\mathrm{NH}_{4}{ }^{+} . \mathrm{NO}_{3}=$ nitrate. $\mathrm{NO}_{\mathrm{x}}=$ nitrogen oxide. $\mathrm{N}_{2} \mathrm{O}=$ nitrous oxide. $\mathrm{NO}_{\mathrm{y}}=$ all oxidized forms of nitrogen other than $\mathrm{N}_{2} \mathrm{O} . \mathrm{N}_{\text {org }}$ = organic nitrogen. $N_{r}=$ reactive nitrogen. $N_{2}=$ nitrogen gas (nonreactive nitrogen).

$\mathrm{N}$ within the treatment plant's service area. This approach would require careful, thoughtful social changes that would mean reducing the size of the user population or changing its consumptive habits. Both are possible but would be difficult to achieve. Similar arguments can be made against source control in the agricultural and energy sectors.

Reactive Nitrogen Management Strategy: Wetland Restoration. Wetland restoration is one of the most promising strategies for reducing $\mathrm{N}$ loads in surface waters, especially in systems like the Mississippi River where $\mathrm{N}$ loads are predominately $\mathrm{NO}_{3}$ (Mitsch et al. 1999, 2001, 2005). Restoring wetlands would provide sufficient space and time for reactive $\mathrm{N}$ management. Rather than defined riverbanks and channels, broad, shallow marshes would border slow moving, sinuous threads of open water measuring only a few feet deep. Grade control, in the form of low weirs (e.g., beaver dams), would ensure adequate residence time for natural biochemical processes to reduce $\mathrm{N}$ loads.
Of course, the resulting shallow marshes would need to give way to greater expanses of open water and deeper channels where other uses, such as commercial navigation, need to be accommodated. Levees would be breached, although not necessarily removed, to allow the river to once again flow into and across its floodplain. Where row crop agriculture once was practiced, wetlands would be recultivated, providing the shallow water habitat needed to maximize denitrification-stable substrate and food for the necessary microbial populations. Denitrification, representing a form of source control, would reduce the aquatic load of reactive $\mathrm{N}$ relentlessly moving toward our coastal waters.

Not only would the morphology be changed but so would the hydrology, botanic structure, and wildlife communities. As argued by Jacobson and Galat (2006) for the Missouri River, rebuilding shallow water habitat can be extremely important to the rehabilitation of river systems. Shallow water habitat encompasses the very morphology needed to maximize denitrification. The restored ecosystems would look and function very differently than they do today.

Restoration Scale. As an answer to the enormous loss of property caused by the 1993 floods in the upper Mississippi River Basin, the restoration of 5.3 million ha (13 million ac) of wetland was proposed for floodwater storage (Hey and Philippi 1995). Along with the flood storage benefits, the authors noted the substantial collateral benefits to water quality improvement. An economic comparison between wetlands and conventional wastewater treatment to address the USEPA's recommended nutrient criteria at seven wastewater treatment facilities in Illinois showed that 76,500 ha $(189,000 \mathrm{ac})$ of restored floodplain wetlands were required to meet monthly demand requirements (Hey et al. 2005). This land area represents half of the Illinois River's 160,000 ha $(400,000$ ac $)$ floodplain, of which 80,000 ha $(200,000 \mathrm{ac})$ are currently leveed (IFMRC 1994) and could make ideal control points for reactive N. Mitsch et al. (2001, 2005; Mitsch and Day 2006) estimated that 2 million ha (5 million ac) of created and restored wetlands in the 
Mississippi-Ohio-Missouri basins could remove $40 \%$ of the $\mathrm{N}$ load to the Gulf of Mexico. A 30\% reduction in $\mathrm{NO}_{3}-\mathrm{N}$ discharged to the Gulf of Mexico could be achieved through the strategic placement of 210,000 to 450,000 ha $(519,000$ to $1,110,000 \mathrm{ac}$ ) of wetland pools in the upper Mississippi River and Ohio River basins (Crumpton et al. 2007). The land is available, as documented in table 1 .

Siting Restoration. Within the aquatic environment, some areas are better than others for controlling reactive N. Streams and rivers offer some control, but they may flow too fast and may be turbulent and/or turbid. Furthermore, they may support too many conflicting and competing highervalue interests: navigation, flood control, and agricultural drainage. Lakes are too deep, offer too little wetted surface area, and support high-value recreational and water supply interests. Wetlands are preferable because they occupy the appropriate landscape position, could provide large wetted surface area, and, although they are often farmed, their economic value for agricultural production is limited by poor drainage and frequent flooding. Therefore, riverine wetlands, or wetlands that are riparian to a stream or river, provide the best aquatic niche to control reactive $\mathrm{N}$.

Site location is essential in wetland restoration. Restored wetlands cannot be effectively and efficiently implemented in just any landscape or landscape position. They can be best applied with the proper hydrologic conditions: shallow and slow moving. They also must be connected to the $\mathrm{N}$ source. The closer the restored wetlands are to higher $\mathrm{N}$ concentrations,

\section{Table 1}

Wetland restoration opportunities in the upper Mississippi River Basin (Hey et al. [2004]).

\begin{tabular}{lcccc}
\hline State & $\begin{array}{l}\text { Total 100-year } \\
\text { flood zone (ha) }\end{array}$ & $\begin{array}{l}\text { Pre-settlement } \\
\text { wetlands (ha) }\end{array}$ & $\begin{array}{c}\text { Total cropland in } \\
\text { flood zone (ha) }\end{array}$ & $\begin{array}{l}\text { Cropland on hydric } \\
\text { soil (ha) }\end{array}$ \\
\hline Illinois & 960,000 & 400,000 & 480,000 & 300,000 \\
lowa & $2,810,000$ & 900,000 & $1,140,000$ & 370,000 \\
Minnesota & 930,000 & 510,000 & 140,000 & 70,000 \\
Missouri & $1,950,000$ & 600,000 & 850,000 & 340,000 \\
Wisconsin & 810,000 & 370,000 & 230,000 & 110,000 \\
\hline Total & $7,470,000$ & $2,790,000$ & $2,840,000$ & $1,190,000$ \\
\hline
\end{tabular}

the more efficient the mass reduction will be. This would argue for restoration located further upstream in an agricultural watershed where $\mathrm{NO}_{3}$ is concentrated in drainage ditches or near the outfall of a municipal wastewater treatment plant. Moving downstream, as reactive $\mathrm{N}$ becomes dilute, greater and greater wetland area will be needed for every ton of reactive $\mathrm{N}$ removed.

These criteria (i.e., hydrology and $\mathrm{N}$ load) narrow the search. They put the wetland on the floodplain. All of the necessary information for site selection is readily available from federal and state databases (e.g., hydric soils, floodplains or flood zones, land use, reactive $\mathrm{N}$ load). A flood storage study identified ample floodplain areas that could provide an environmental flood control solution and, at the same time, serve to control N (Hey et al. 2004).

Financing Restoration. The costs and benefits were determined for converting all 2.8 million ha (7 million ac) of cropland within the upper Mississippi River Basin 100-year flood zone to wetlands for flood control purposes (Hey et al. 2004). The three categories of social benefits included the cost avoided by the elimination of crop damage by flooding, hail, and other natural calamities (paid by the federal government through insurance subsidies and emergency services); the elimination of crop subsidies (paid by the federal government in support of crop prices); and the recreational opportunities (hunting, fishing, and bird watching) that the restored wetlands would afford. These benefits total US $\$ 2.1$ billion $\mathrm{y}^{-1}$ (table 2). On the other side of the ledger, lost farm income (represented by "average rental income") and wetland construction, restoration, and operation costs totaled US $\$ 1.6$ billion $\mathrm{y}^{-1}$. Thus, the net social benefits from 2.8 million ha of wetland restored on cropland within the 100-year floodplain were found to be a positive US $\$ 494$ million. If the economic value of reactive $\mathrm{N}$ control were added to the net social benefit, the economic viability of wetland restoration would be even more robust.

Based on the required demand of the point source dischargers in the Illinois River Watershed, between 26,000 and

\section{Table 2}

Net social benefits of converting all cropland within the Upper Mississippi River Basin 100-year flood zone to wetlands for flood control (Hey et al. [2004]).

\begin{tabular}{|c|c|c|c|c|c|c|c|c|}
\hline \multirow[t]{2}{*}{ State } & \multicolumn{4}{|c|}{ Annual social benefits (million US\$) } & \multicolumn{3}{|c|}{ Annual social costs (million US\$) } & \multirow{2}{*}{$\begin{array}{l}\text { Total annual net } \\
\text { benefits (million US\$) }\end{array}$} \\
\hline & $\begin{array}{l}\text { Elimination of } \\
\text { crop damages }\end{array}$ & $\begin{array}{l}\text { Elimination of } \\
\text { crop subsidies }\end{array}$ & $\begin{array}{l}\text { Non-flood } \\
\text { wetland benefits }\end{array}$ & $\begin{array}{l}\text { Total annual } \\
\text { benefits }\end{array}$ & $\begin{array}{l}\text { Average rental } \\
\text { income }\end{array}$ & $\begin{array}{l}\text { Wetland } \\
\text { costs }\end{array}$ & $\begin{array}{l}\text { Total annual } \\
\text { costs }\end{array}$ & \\
\hline Illinois & 61 & 35 & 260 & 356 & 131 & 143 & 275 & 81 \\
\hline lowa & 149 & 104 & 614 & 867 & 290 & 338 & 628 & 239 \\
\hline Minnesota & 18 & 7.2 & 74 & 99 & 28 & 41 & 68 & 30 \\
\hline Missouri & 80 & 53 & 457 & 590 & 256 & 252 & 507 & 83 \\
\hline Wisconsin & 33 & 10 & 126 & 169 & 39 & 69 & 108 & 61 \\
\hline Total & 342 & 209 & 1,531 & 2,082 & 744 & 843 & 1,587 & 494 \\
\hline
\end{tabular}




\begin{tabular}{|c|c|c|c|}
\hline Parameter & Unrestricted & Restricted intrawatershed & Accrued $10 \%$ penalty \\
\hline Maximum wetland area (ha) & 121,000 & 121,000 & 148,000 \\
\hline Total credits sold (t of total nitrogen) & 26,000 & 26,000 & 32,000 \\
\hline Total revenue (US\$)* & $69,925,000$ & $99,572,000$ & $121,458,000$ \\
\hline Total cost to produce credits (US\$) & $63,258,000$ & $66,194,000$ & $83,289,000$ \\
\hline Profit (US\$) & $6,667,000$ & $33,378,000$ & $38,169,000$ \\
\hline
\end{tabular}

$32,000 \mathrm{t}(29,000$ and $36,000 \mathrm{tn})$ of total $\mathrm{N}$ would need to be removed annually by the restored and managed wetlands under the three studied trading schemes (table 3 ). The range of removal is a function of the market restrictions imposed by oversight or regulatory agencies. Accordingly, the market revenue would range from US $\$ 70$ million to US\$121 million $\mathrm{y}^{-1}$. This is a sizeable market that could generate substantial profits, from US\$6 million to US\$38 million, with a return on investment ranging from $5 \%$ to $25 \%$. If the savings are shared evenly between the seller and buyer, the seller or landowner could earn between US $\$ 500$ and US $\$ 700 \mathrm{ha}^{-1} \mathrm{y}^{-1}$ (US $\$ 202$ and US $\$ 283 \mathrm{ac}^{-1} \mathrm{yr}^{-1}$ ) net profit, which is considerably greater than typical profits from corn or soy bean production. In addition, $\mathrm{N}$ credit profits do not include any earnings from other ecosystem services (e.g., floodwater storage, recreation, biodiversity). There is little doubt that the wetland strategy for controlling reactive $\mathrm{N}$ could easily pay for itself without government subsidies.

\section{CRITICAL QUESTIONS}

Given the evidence of well over 30 years of systematic wetland research in the United States and around the world, there is little doubt that wetlands can do the job of managing reactive $N$. Still, in a few cases, more rigorous analyses need to be done. First, the question of wetland longevity in regard to nutrient removal is an issue of importance. Second, is the question of the role of wetlands in regards to climate change: do wetlands produce greenhouse gases (GHG) in greater amounts than they sequester or transform into inert substances? These questions and those related to the large-scale management of restored wetlands for water quality management can and should be answered through appropriately scaled pilot projects.

\section{DO WETLANDS WEAR OUT?}

The assumption that wetland efficacy "wears out" as a wetland ages is a common misconception about wetlands restored or created for the purposes of water quality improvement or treatment. The incorrect conclusions about wetland removal longevity comes from an incomplete understanding of wetland nutrient processing, efficiencies, and removal mechanisms, particularly in regard to phosphorus. The overall performance, or the efficiency of a wetland to retain or remove nutrients, is a factor of loading rate, hydraulic residence time, and availability of substrate for microbial communities (Phipps and Crumpton 1994; Woltemade 2000; Fisher and Acreman 2004). There is an extensive and ever expanding body of literature that clearly explains the performance, nutrient transformation and storage, and design and operating strategies for emergent marsh systems designed for water quality improvement or wastewater treatment (Kadlec and Knight 1996; Kadlec and Wallace 2008).

Nitrogen is mostly found in the form of $\mathrm{NO}_{3}-\mathrm{N}$ in water. Emergent marshes can be effective for $\mathrm{NO}_{3}-\mathrm{N}$ removal through denitrification, the primary $\mathrm{N}$ removal mechanism. Denitrification, where $\mathrm{NO}_{3}$ is reduced to $\mathrm{N}_{2}$, is a microbial process and therefore does not have any life expectancy limitations (Hernandez and Mitsch $2007 \mathrm{a}, 2007 \mathrm{~b})$. The rate of denitrification is affected by a number of factors, including the presence of oxygen, temperature,
$\mathrm{pH}$, and the availability of carbon (C), particularly at high $\mathrm{NO}_{3}$ loadings. However, most mature wetlands produce $\mathrm{C}$ in sufficient quantities to support the $\mathrm{NO}_{3}$ loads anticipated in the upper Midwest. Nitrate removal performance improves at higher water temperatures and with increased hydraulic efficiency. Wetlands have been validated by numerous scientific studies in regard to efficient $\mathrm{N}$ removal (Fisher and Acreman 2004; Kadlec and Wallace 2008).

In contrast to nitrate, phosphorus is not completely removed from the wetland system. Phosphorus removal and storage mechanisms include sedimentation, chemical precipitation, adsorption, and plant uptake (Mitsch and Gosselink 2007). However, accretion is the principal longterm (and sustainable) removal mechanism for phosphorus (Craft and Richardson 1993; Reddy et al. 1993; Rybczyk et al. 2002; Kadlec and Wallace 2008). Accretion is the creation of new soil/sediment material from remnant macrophyte stem and leaf debris, remnant dead roots and rhizomes, and indecomposable fractions of dead phytoplankton, benthic algae, bacteria, fungi, invertebrates, etc. The majority of the assimilated phosphorus is released during decomposition, but $10 \%$ to $20 \%$ is permanently stored as the residual from the decomposition process (Kadlec and Wallace 2008). This process only requires a long hydroperiod to prevent oxidative release. This bioaccretion fraction is augmented by the sedimentation of incoming suspended particulate material.

If the wetland is adequately maintained and measures are taken to accommodate accretion, then there is no apparent limit to wetland lifetime for phosphorus removal. Kadlec (2009) provides quantitative evidence that wetlands do not experience a "wearing out" phenomenon for phosphorus. This is borne out in the performance of wetlands that have been receiving nutrient laden discharges for long periods of time (Kadlec and Wallace 2008).

\section{ARE WETLANDS NET PRODUCERS OF GREENHOUSE GASES?}

Greenhouse gases are of concern in today's world. These include carbon dioxide $\left(\mathrm{CO}_{2}\right)$, methane $\left(\mathrm{CH}_{4}\right)$, and nitrous oxide $\left(\mathrm{N}_{2} \mathrm{O}\right)$, or other forms of reactive $\mathrm{N}$, all 
of which are involved in wetland biogeochemistry. Considerable amounts of $\mathrm{CO}_{2}$ are utilized by the wetland plants, some of which end up in newly formed soils which sequester $\mathrm{C}$. So, wetlands are almost always $\mathrm{CO}_{2}$ sinks. In fact, $\mathrm{C}$ sequestration in wetlands may be significantly underestimated on a global scale (Lenart 2009). However, $\mathrm{CH}_{4}$ and $\mathrm{N}_{2} \mathrm{O}$ are emitted by many wetland ecosystems. Mitsch et al. (2010, n.d.) have pointed out that $\mathrm{CH}_{4}$ emissions are "trumped" by $\mathrm{C}$ sequestration in almost all wetlands when $\mathrm{CH}_{4}$ decay in the atmosphere is accounted for, even though a molecule of $\mathrm{CH}_{4}$ emitted is 25 times more effective at global warming than is a molecule of $\mathrm{CO}_{2}$ retained in the wetlands. This is in support of previous summaries by Roulet (2000) and Joosten and Clark (2002) for northern peatlands that have $\mathrm{C}$ sequestration and $\mathrm{CH}_{4}$ emission rates lower than temperate (discussed here) and tropical wetlands (Mitsch et al. n.d.). Although this gas is a potent contributor to the total emissions, it represents only about $5 \%$ of the total (USEPA 2008).

Overall, it appears that treatment wetlands in the Mississippi River Basin will have no negative GHG effect when the decay of $\mathrm{CH}_{4}$ is taken into account. Furthermore, the wetland GHG balance has a further advantage in the Midwest as these wetlands often replace and offset the poor GHG balance (low C sequestration and high $\mathrm{N}_{2} \mathrm{O}$ emissions) of the marginally productive agricultural lands which restored wetlands would typically replace. In addition, denitrification in freshwater wetlands produces a lower fractional $\mathrm{N}_{2} \mathrm{O}$ yield than would otherwise be produced in downstream riverine and marine systems.

There is seasonality in wetland emissions of $\mathrm{CH}_{4}$ and $\mathrm{N}_{2} \mathrm{O}$ in Midwestern created and restored wetlands (Hernandez and Mitsch 2006; Altor and Mitsch 2008; Nahlik and Mitsch 2010; Sha et al. 2011), with larger fluxes in the unfrozen months. Unfortunately, the warmer seasons are also the time of maximal nutrient removal. Nitrate is more effectively reduced at warm temperatures as it is microbially mediated, and $\mathrm{P}$ removal is greater through spring and summer due to uptake and incorporation into plant biomass during the growing season. Operating strategies designed to minimize GHG emissions by avoiding the warm season could impair nutrient removal. However, $\mathrm{NO}_{3}$ loads from nonpoint sources are greatest during cooler, high flow periods in the spring and late fall

\section{RECOMMENDATIONS}

Strategic wetland creation and restoration could provide a large-scale, effective, efficient, and sustainable solution to the threat of the growing presence of reactive $\mathrm{N}$ in the biosphere. Other control measures, such as point source control, still will be needed. However, they do not offer the necessary magnitude of control and often result in adverse unintended consequences due to increased energy demand and hence C emissions. On the other hand, wetland restoration can and will provide numerous ancillary environmental benefits, including sediment and nutrient retention, climate change mitigation, floodwater control, wildlife habitat expansion, biodiversity reservoirs, recreation and tourism opportunities, and additional income sources.

Before a wetland restoration strategy for reactive $\mathrm{N}$ management is embarked upon, however, the following questions need answers:

- What are the costs, in terms of human and environmental health and capital resources, of excessive amounts of reactive $\mathrm{N}$ in the biosphere?

- Should capital and energy be spent on upgrading conventional wastewater treatment plants if this control strategy would increase emissions of reactive $\mathrm{N}$ to atmospheric and terrestrial media?

- What are the alternative control strategies that might be used in the aquatic environment?

- If restored wetlands were used to control reactive $\mathrm{N}$, what would this strategy look like on the ground and what would be the ancillary benefits and their economic value to society?

- On an annual basis, how many tons of reactive $\mathrm{N}$ needs to be removed from the aquatic environment and how should the load reduction be distributed spatially?

- What area of restored wetlands would be required to achieve adequate con- trol of existing and future projected reactive $\mathrm{N}$ loads?

- For each strategy, what would be the cost for systemic control, measured in dollars and kilowatt-hours?

- What are the relative scale, effectiveness, efficiency, and sustainability of each strategy?

- How will the controls be financed and maintained?

Research into the environmental effects, economics, and policy implications of using restored freshwater wetlands to control reactive $\mathrm{N}$ should be promoted. Some of the topics of particular concern include the following:

- Greenhouse gas emissions under various design and operating conditions

- Optimization of reactive $\mathrm{N}$ control

- Fate and bioaccumulation of potentially hazardous substances, such as mercury

- Wetland policy guidelines

- Farm income

- Ownership, verification, and certification of water quality credits

- Market structure and governance

To answer these questions, federal, state, and local agencies along with private sector organizations should closely coordinate their efforts. Programmatically related agencies such as the USDA, USEPA, Department of Interior, US Army Corps of Engineers, and Federal Emergency Management Agency should work together in developing policies and strategies to support $\mathrm{N}$ reduction. They should also significantly enhance their respective extramural research programs to answer many of the uncertainties listed above.

Much of the required landscape data are available in various federal, state, and local databases, but access is time consuming and often data are not current. In this regard, the USEPA, US Geological Survey, and the USDA should complete the National Hydrographic Database. It is important that this database be expanded and updated to provide all of the physical information (e.g., stream gradients, floodplain areas, land use on floodplains, hydric soils, existing/restored wetland status) needed to evaluate water quality and ancillary benefits of alternative wetland restoration strategies. Of course, the 
database will not solve the problems of too much reactive $\mathrm{N}$ in the air, land, and water, but it could provide a better basis for addressing the problems. Hopefully, these arguments will convince scientists and policy makers to take action. The USDA and the USEPA need to develop the requisite national database, promulgate guidance policies, and support a research effort when and where leadership is lacking. Both agencies should expect local governments, industries, foundations, and conservations organizations, which all have a considerable interest in the subject, to help with the research and development costs.

In the end, two developments are essential for control of excess $\mathrm{N}$ : nutrient standards in every state and associated, regulated water quality trading markets of instruments (contracts). Conventional treatment is too expensive and requires too much energy. The water quality trading strategy requires little of the federal and state agencies except for monitoring and governance. The land would remain in the control and ownership of the existing farmer, and restoration of the critical wetlands would be financed from the sale of water quality credits or other income such as hunting and fishing. The public would be spared a major tax hike and would benefit from the expanded wildlife habitat, flood control, open space, and a whole new industry, which would generate employment opportunities, income, and public revenue.

\section{REFERENCES}

Altor, A.E., and W.J. Mitsch. 2008. Methane emissions and carbon dioxide fluxes in created wetland mesocosms: Effects of hydrologic regime and hydric soils. Ecological Applications 18(5):1307-1320.

Birch, M.B.L., B.M. Gramig, W.R. Moomaw, O.C. Doering III, and C.J. Reeling. 2011. Why metrics matter: Evaluating policy choices for reactive nitrogen in the Chesapeake Bay watershed. Environmental Science \& Technology 45(1):168-174.

Craft, C.B., and C.J. Richardson. 1993. Peat accretion and $\mathrm{N}, \mathrm{P}$, and organic $\mathrm{C}$ accumulation in nutrient-enriched and unenriched Everglades peatlands. Ecological Applications 3(3):446-458.
Crumpton, W., G. Stenback, B. Miller, and M. Helmers. 2007. Potential Benefits of Wetland Filters for Tile Drainage Systems: Impact on Nitrate Loads to Mississippi River Subbasins. Washington, DC: USDA.

Dias, R.J., and A. Solow. 1999. Ecological and Economic Consequences of Hypoxia, Topic 2 Report for the Integrated Assessment of Hypoxia in the Gulf of Mexico. NOAA Coastal Ocean Program and Decision Analysis Series No. 16. Silver Spring: NOAA Coastal Ocean Program.

Fisher, J., and M.C. Acreman. 2004. Wetland nutrient removal:A review of the evidence. Hydrology and Earth System Sciences 8(4):673-685.

Galloway, J.N., J.D. Aber, J.W. Erisman, S.P. Seitzinger, R.W. Howarth, E.B. Cowling and J. Cosby. 2003. The nitrogen cascade. BioScience 53(4):341-356

Goolsby, D.A., and W.A. Battaglin. 2000. Nitrogen in the Mississippi Basin-Estimating Sources and Predicting Flux to the Gulf of Mexico. USGS Fact Sheet 135-00. Denver: US Geological Survey.

Goolsby, D.A., W.A. Battaglin, G.B Lawrence, R.S. Artz, B.T.Aulenbach, R.P. Hooper, D.R. Keeney, and G.J. Stensland. 1999. Flux and Sources of Nutrients in the Mississippi-Atchafalaya River Basin, Topic 3 Report for the Integrated Assessment of Hypoxia in the Gulf of Mexico. NOAA Coastal Ocean Program and Decision Analysis Series No. 17. Silver Spring: NOAA Coastal Ocean Program.

Hernandez, M.E., and W.J. Mitsch. 2006. Influence of hydrologic pulses, flooding frequency, and vegetation on nitrous oxide emissions from created riparian marshes. Wetlands 26(3):862-877.

Hernandez, M.E., and W.J. Mitsch. 2007a. Denitrification in created riverine wetlands: Influence of hydrology and season. Ecological Engineering 30(1):78-88.

Hernandez, M.E., and W.J. Mitsch. 2007b. Denitrification potential and organic matter as affected by vegetation community, wetland age, and plant introduction in created wetlands. Journal of Environmental Quality 36(1):333-342.

Hey, D.L., J.A. Kostel, A.P. Hurter, and R.H. Kadlec. 2005. Comparing Economics of Nitrogen Farming with Traditional Removal. WERF 03-WSM-6CO. Alexandria, VA: Water Environment Research Foundation.

Hey, D.L., D.L. Montgomery, L.S. Urban, T. Prato, F. Andrew, M. Martel, J. Pollack, Y. Steele, and R. Zarwell. 2004. Flood Damage Reduction in the Upper Mississippi River Basin: An Ecological Alternative. Minneapolis, MN: McKnight Foundation.
Hey, D.L., and N.S. Philippi. 1995. Flood reduction through wetland restoration: The upper Mississippi River basin as a case history. Restoration Ecology 3(1):4-17.

Howarth, R., R. Ramakrishna, E. Choi, R. Elmgren, L. Martinelli, A. Mendoza, W. Moomaw, C. Palm, R. Rabindra, M. Scholes, and Z. Zhao-Ling. 2005. Nutrient management. In Millennium Ecosystem Assessment. Washington, DC: Island Press.

IFMRC (Interagency Floodplain Management Review Committee). 1994. Sharing the Challenge: Floodplain Management into the 21st Century. Report of the Interagency Floodplain Management Review Committee. Washington, DC: US Government Printing Office.

Jacobson, R.B., and D.L. Galat. 2006. Flow and form in rehabilitation of large-river ecosystems: An example from the Lower Missouri River. Geomorphology 77:249-269.

Joosten, H., and D. Clarke. 2002. Wise Use of Mires and Peatlands-Background Principles including a Framework for Decision-Making. Finland: International Mire Conservation Group and International Peat Society. http://www.mirewiseuse.com.

Kadlec, R.H. 2009. Wastewater treatment at the Houghton Lake, Michigan: Hydrology and water quality. Ecological Engineering 35(9):1287-1311.

Kadlec, R.H., and R.L. Knight. 1996. Treatment Wetlands. New York: CRC Lewis Publishers.

Kadlec, R.H., and S.D. Wallace. 2008. Treatment Wetlands, 2nd ed. Boca Raton, FL: CRC Press.

Kostel, J.A., R.M. Peck, B. Scott, and C. Tallarico. 2008. The economics of nutrient farming. Chicago, IL: Kinship Foundation, The Wetlands Initiative.

Lenart, M. 2009. An unseen carbon sink. Nature Reports Climate Change 26 November 2009. Nature Publishing Group. doi:10.1038/ climate/2009/125.

Mitsch, W.J., J.W. Day, J.W. Gilliam, P.M. Groffman, D.L. Hey, G.W. Randall, and N. Wang. 1999. Reducing nutrient loads, especially nitratenitrogen, to surface water, ground water, and the Gulf of Mexico, Topic 5 report for the Integrated Assessment of Hypoxia in the Gulf of Mexico. NOAA Coastal Ocean Program and Decision Analysis Series No. 19. Silver Spring: NOAA Coastal Ocean Program.

Mitsch, W.J., J.W. Day, J.W. Gilliam, P.M. Groffman, D.L. Hey, G.W. Randall, and N. Wang. 2001. Reducing nitrogen loading to the Gulf of Mexico from the Mississippi River Basin: 
Strategies to counter a persistent ecological problem. BioScience 51(5):373-388.

Mitsch, W.J., J.W. Day, L. Zhang, and R. Lane. 2005. Nitrate-nitrogen retention by wetlands in the Mississippi River Basin. Ecological Engineering 24: 267-278.

Mitsch, W.J., and J.W. Day. 2006. Restoration of wetlands in the Mississippi-Ohio-Missouri (MOM) River Basin: Experience and needed research. Ecological Engineering 26:55-69.

Mitsch, W.J., and J.G. Gosselink. 2007. Wetlands, 4th ed. New York: John Wiley \& Sons.

Mitsch, W.J., A.M. Nahlik, P. Wolski, B. Bernal, L. Zhang, and L. Ramberg. 2010. Tropical wetlands: Seasonal hydrologic pulsing, carbon sequestration, and methane emissions. Wetlands Ecology and Management 18(5):573-586.

Mitsch, W.J, A.M. Nahlik, B. Bernal, L. Zhang, C.J. Anderson, S.E. Jørgensen, U. Mander, and H. Brix. n.d. Wetlands, carbon, and climate change.

Moomaw, W.R. 2002. Energy, Industry and Nitrogen: Strategies for decreasing reactive nitrogen emissions. Ambio 31(2):184-189.
Nahlik, A.M., and W.J. Mitsch. 2010. Methane emissions from created riparian wetlands. Wetlands 30:783-793.

Phipps, R.G., and W.G. Crumpton. 1994. Factors affecting nitrogen loss in experimental wetlands with different hydrologic loads. Ecological Engineering 3:399-408.

Rabalais, N.N. 2002. Nitrogen in aquatic ecosystems. Ambio 31(2):102-112.

Rabalais, N.N., R.E. Turner, and D. Scavia. 2002a. Beyond science into policy: Gulf of Mexico hypoxia and the Mississippi River. BioScience 52(2):129-142.

Rabalais, N.N., R.E. Turner, and W.J. Wiseman. 2002b. Hypoxia in the Gulf of Mexico, a.k.a. “The Dead Zone." Annual Review of Ecology and Systematics 33:235-263.

Reddy, K.R., R.D. DeLaune, W.F. DeBusk, and M. Koch. 1993. Long-Term Nutrient Accumulation Rates in the Everglades. Soil Science Society of America Journal 57:1147-1155.

Roulet, N.T. 2000. Peatlands, carbon storage, greenhouse gases, and the Kyoto protocol: Prospects and significance for Canada. Wetlands 20(4):605-615.
Rybczyk, J.M., J.W. Day, and W.H. Conner. 2002.The impact of wastewater effluent on accretion and decomposition in a subsiding forested wetland. Wetlands 22(1):18-32.

Sha, C., W.J. Mitsch, Ü. Mander, J. Lu, J. Batson, L. Zhang, and W. He. 2011. Methane emissions from freshwater riverine wetlands. Ecological Engineering 37:16-24.

USEPA (US Environmental Protection Agency). 2008. Inventory of U.S. Greenhouse Gas Emissions and Sinks: 1990-2006. EPA 430-R08-005. Washington, DC: USEPA.

Woltemade, C.J. 2000. Ability of restored wetlands to reduce nitrogen and phosphorus concentrations in agricultural drainage water. Journal of Soil and Water Conservation 55(3):303-309. 